\title{
Highly Turbocharging a Flow Restricted Two Cylinder Small Engine - Turbocharger Development
}

\author{
William Attard, Harry C. Watson and Steven Konidaris \\ University of Melbourne
}

Copyright @ 2007 SAE International

\begin{abstract}
This paper describes the turbocharger development of a restricted $430 \mathrm{~cm}^{3}$ odd firing two cylinder engine. The downsized test engine used for development was specifically designed and configured for Formula SAE, SAE's student Formula race-car competition.

A well recognised problem in turbocharging Formula SAE engines arises from the rules, which dictate that the throttle and air intake restrictor must be on the suction side of the compressor. As a consequence of upstream throttling, oil from the compressor side seal assembly is drawn into the inlet manifold. The development process used to solve the oil consumption issue for a Garrett GT12 turbocharger is outlined, together with cooling and control issues.
\end{abstract}

The development methodology used to achieve high pressure ratio turbocharging is discussed, along with exhaust manifold development and operating limitations. This includes experimental and modeling results for both pulse and constant pressure type turbocharging.

The engine completed extensive static and transient testing with no turbocharger issues after initial development. Peak values of 25 bar brake mean effective pressure (BMEP) were recorded while running on pump gasoline.

\section{INTRODUCTION AND BACKGROUND}

The design brief for the engine featured specific downsizing when compared to the typical four cylinder $600 \mathrm{~cm}^{3}$ maximum capacity engines used in the Formula. Brake power could also be increased, as the maximum mass flow was limited by the mandatory 20 $\mathrm{mm}$ diameter intake restriction. If the restriction could be choked, delivered power would increase due to the reduction in frictional losses associated with the smaller capacity $[1,2,3,4,5]$.

To compensate for the reduced capacity, the engine featured high pressure ratio turbocharging with maximum boost levels dictated by turbocharger limits. Turbocharging offered improved efficiency and allowed the maximum mass flow through the restrictor to be maintained over a wide speed range $[1,2,3,4,5]$. This had advantages in reducing fuel consumption and improving on-track drivability in Formula competition $[2,6]$.

However, challenges were faced in the selection and procurement of a turbocharger, due to the engine's small size. A background search revealed very few units which fulfilled the airflow and corresponding pressure ratio requirements. Problems were also faced due to Formula rules, which regulated upstream throttle and restrictor locations in order to limit airflow. This mandatory layout (Figure 1) significantly increased the difficultly of implementing a turbocharged (TC) intake system. At part load or restrictor choking conditions, the manifold vacuum generated would induce engine oil from the turbocharger lubrication system into the compressor housing and thus the intake manifold. This is not only an imposition on the required oil capacity, but also causes major combustion problems ranging from plug fouling to increased probability of pre-ignition and/or end-gas knock. These issues all contribute to a significant reduction in engine performance and reliability, often resulting in clouds of white smoke being emitted from TC Formula vehicles.

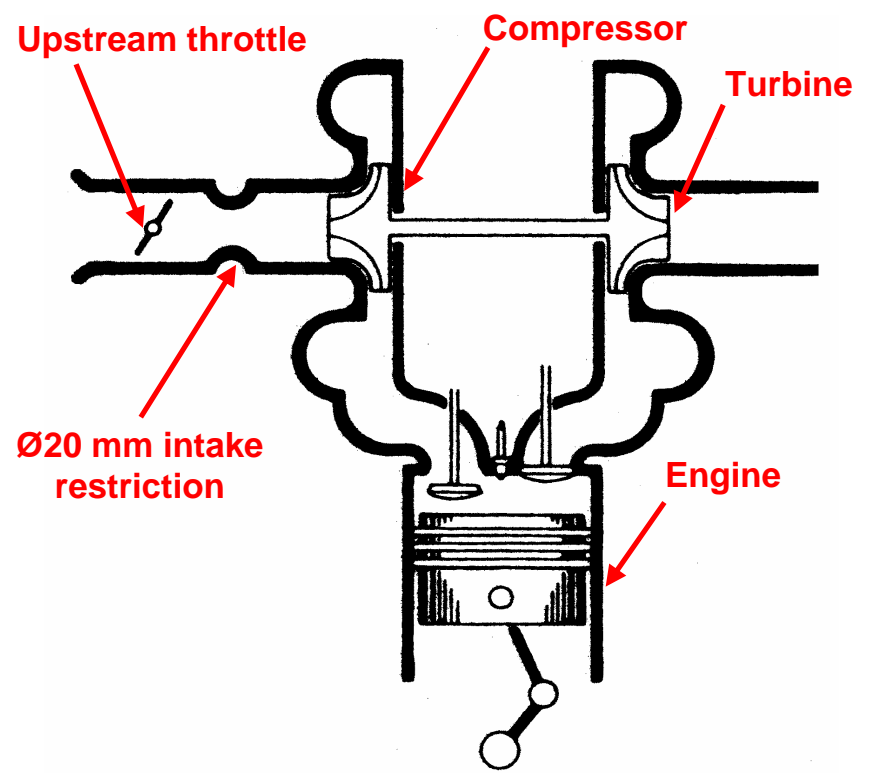

Figure 1: Formula SAE regulated turbocharger layout and resulting upstream compressor throttling. 
Despite the drawbacks, upstream throttling in TC applications has many benefits, including reduced turbolag and increased spool rates during engine transience $[7,8,9]$. However, these benefits are normally outweighed by the oil control issues previously highlighted. The turbochargers found in most modern day vehicles are designed to operate under non-throttled compressor conditions. As a result of this design layout, modern day turbochargers feature reliable piston ring type oil seals as there is no suction on the compressor side. This type of seal has many advantages when compared to the outdated carbon face seal design [8]. However, these seals fail to generate a complete seal, and thus are susceptible to this oil consumption issue when implemented as in Figure 1. This seal leakage is not important under non-throttled conditions as compressor pressures are always equal to or higher than atmospheric. This results in small amounts of intake air bleeding into the turbocharger lubrication drain system, which is recycled with blow-by into the intake manifold or vented to the atmosphere. Thus the modern turbocharger design limits applications to conditions where compressors are non-throttled.

The oil control issues associated with modern turbochargers in compressor throttled applications have previously been overcome using carbon face seals. The carbon face seal design has been proven to successfully operate under throttled conditions $[8,10,11]$. However, the design is more costly to implement, with oil seal longevity and performance becoming major issues, thus limiting the life and reliability of the unit. Shaft loading and spool time are also increased compared to the piston ring design, due to the increased face seal drag. Turbochargers fitted with this design are the only choice for carbureted draw through applications, which are throttled by nature [9]. However, the implementation of fuel injection to engines has resulted in carbon seals becoming obsolete, as there is no market to produce units to suit these applications. As no carbon seal turbochargers were suited to this particular engine, a modern Garrett GT-12 unit was selected.

The original intent of this engine program was to achieve success in Formula competition, using a superior engine package. From the process used to accomplish the project objectives, a variety of interesting findings have been discovered $[1,2,3,4,12]$. This paper focuses on turbocharger implementation, in particular the development needed to control oil consumption in throttled compressors, featuring piston ring type oil seals.

\section{TEST ENGINE}

The test engine used in experiments was specifically designed and developed at the University of Melbourne for use in Formula SAE. The $434 \mathrm{~cm}^{3}$ twin cylinder inline arrangement features double overhead camshafts and four valves per cylinder, along with a three speed transmission and dry sump lubrication. Further specifications are given in Table 1. Figure 2 highlights a sectional view of the engine design and Figure 3 displays the final TC version.
Table 1: Final specifications for the highly TC UniMelb 'WATTARD' engine.

\begin{tabular}{|c|c|}
\hline BRAND & UniMelb 'WATTARD' \\
\hline TYPE & $\begin{array}{l}\text { Parallel twin, } \\
4 \text { stroke SI, } \\
\text { Liquid-cooled, } \\
\text { Integral clutch/ transmission }\end{array}$ \\
\hline CAPACITY & $433.8 \mathrm{~cm}^{3}$ \\
\hline BORE $\times$ STROKE & $69 \times 58 \mathrm{~mm}$ \\
\hline FIRING ORDER & Unequal $\left(0^{\circ}, 180^{\circ} \mathrm{CA}\right)$ \\
\hline COMPRESSION RATIO & 9-13:1 with piston modification \\
\hline COMBUSTION CHAMBER & Pent roof central spark plug \\
\hline VALVE ACTUATION & 8-valve DOHC \\
\hline VALVE TIMING & $\begin{array}{lll}\text { IVO } & 24^{\circ} & \text { BTDC } \\
\text { IVC } & 72^{\circ} & \text { ABDC } \\
\text { EVO } & 57^{\circ} & \text { BBDC } \\
\text { EVC } & 9^{\circ} & \text { ATDC }\end{array}$ \\
\hline LUBRICATION & Dry sump \\
\hline INTAKE & $\begin{array}{l}20 \mathrm{~mm} \text { restrictor - Dall venturi } \\
\text { KEC manifold with PFI, } \\
4.5 \mathrm{~L} \text { plenum volume, } \\
350 \mathrm{~mm} \text { primary intake length, }\end{array}$ \\
\hline EXHAUST & $\begin{array}{l}\text { KEC manifold } \\
2.5 \mathrm{~L} \text { plenum volume }\end{array}$ \\
\hline ENGINE MANAGEMENT & Motec M4 EMS \\
\hline TURBOCHARGER & Garrett GT-12 (modified) \\
\hline CLUTCH & Multi wet plate \\
\hline TRANSMISSION & $\begin{array}{l}\text { Constant mesh, } \\
3 \text { forward gears }\end{array}$ \\
\hline
\end{tabular}

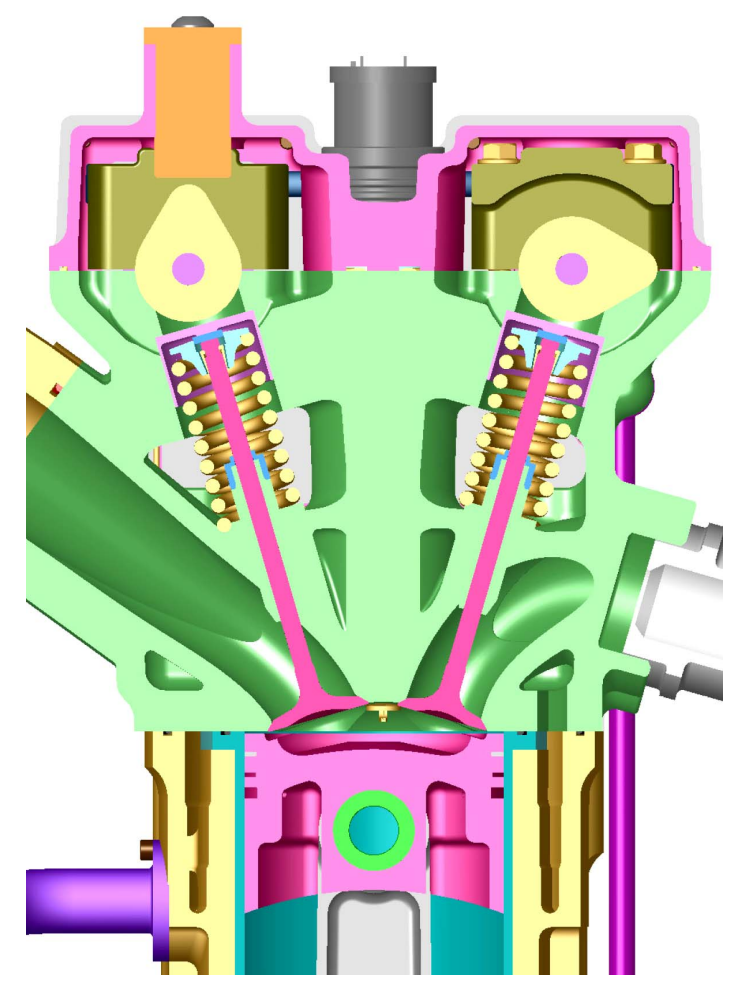

Figure 2: Engine sectional view, highlighting the cylinder head, barrel and reciprocating assembly. 

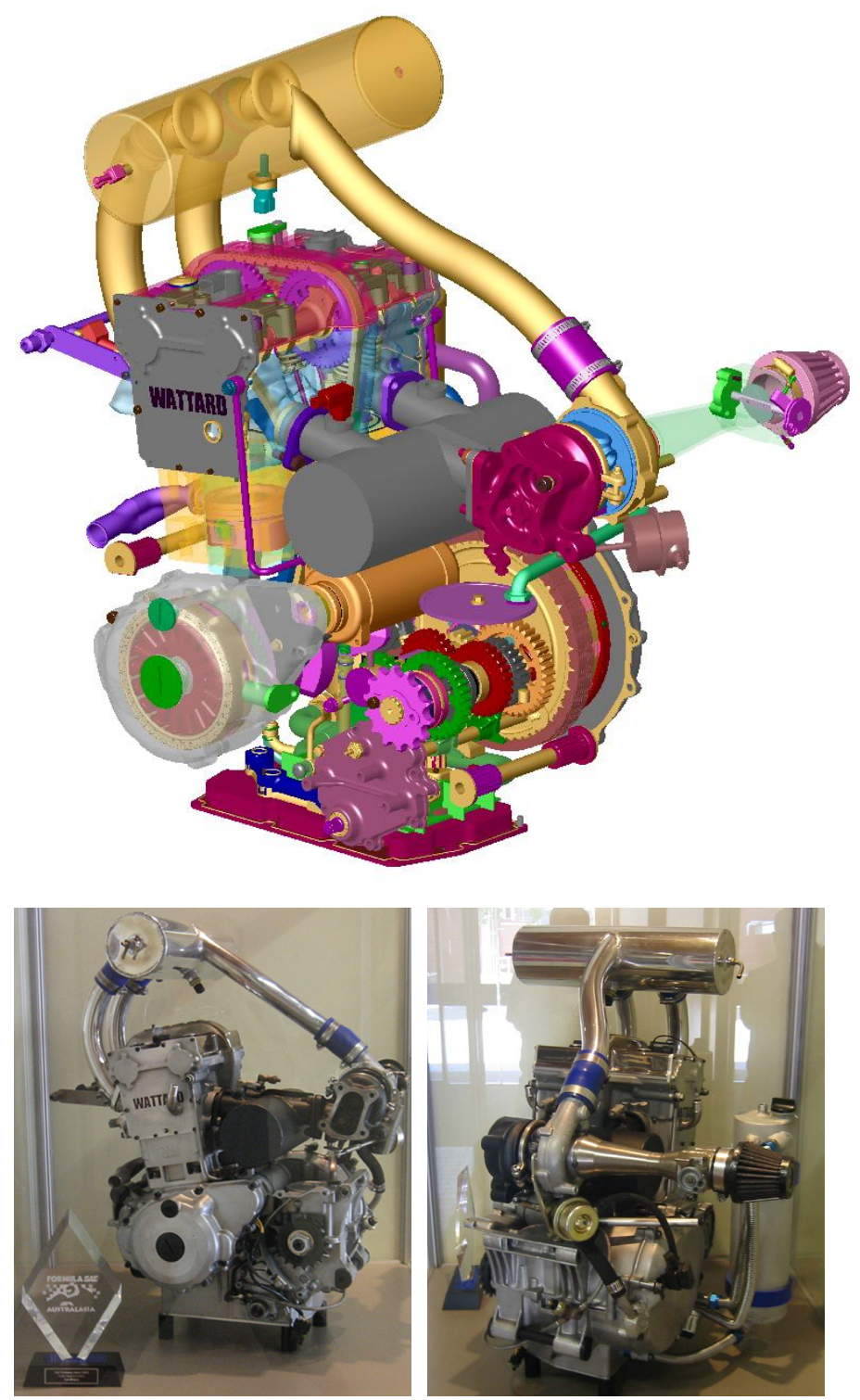

Figure 3: The TC UniMelb 'WATTARD' engine. (Upper): CAD image. (Lower): Final TC version together with the fuel economy trophy from the 2004 Australasian competition.

\section{DEVELOPMENT METHODOLOGY}

Testing began with a variety of normally aspirated (NA) configurations running to maximum speed before commencing boosted development. Boosted operation began with an externally driven positive displacement Rootes type supercharger, with the setup shown in Figure 4. Supercharging enabled parametric constraints to be established in order to find the engine's limitations under mild boost with no exhaust influence. A maximum manifold absolute pressure (MAP) of $150 \mathrm{kPa}$ was desired to evaluate knock severity at low engine speeds and to ensure engine reliability at high compression ratio (CR). The supercharged (SC) data provided valuable insight into the engine modifications needed to sustain high pressure ratio turbocharging $[1,4]$.

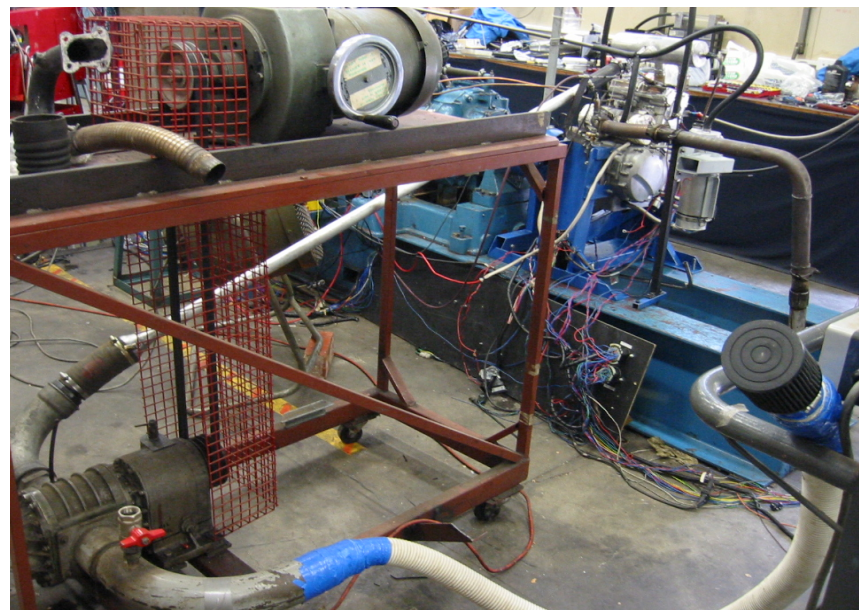

Figure 4: Externally driven Rootes type supercharger setup.

Maximum pressure ratios in the TC mode at wide open throttle (WOT) were dictated by intake restrictor choking limits and corresponding engine speeds. The objective was to maintain a choked restricted inlet at the lowest possible engine speed to broaden and increase the delivered power, which improved vehicle drivability $[1,2,3,4]$. Thus, maximum levels were dictated by turbocharger limitations and were expected to be greater than $250 \mathrm{kPa}$ MAP, which was needed to produce sonic flow through the intake restrictor at mid range speeds.

Testing initially commenced at the highest $\mathrm{CR}$ achievable with a flat top piston in a pent roof combustion chamber corresponding to $13: 1$. It was anticipated that the CR would need to be reduced for boosted operation and provisions were made in the piston design to facilitate this requirement. If knock control could not be achieved through the engine management system (EMS), involving varying degrees of spark retard and/or fuel enrichment, the CR would be decreased in accordance with the knock severity and testing continued to find the limits of operation. The knock $(\mathrm{KL})$ and damage limit $(\mathrm{DL})$, previously published by Rothe [13], were used to determine if CR reductions were needed to ensure engine reliability. The knock amplitude (KA) required to find these limits is defined as the zero to peak pressure of the high pass filtered cylinder pressure.

$$
\begin{aligned}
& >\mathrm{KL} \quad 1 \% \text { cycles with } \mathrm{KA}>4 \text { bar } \\
& >\quad \mathrm{DL} \quad 1 \% \text { cycles with } \mathrm{KA}>20 \text { bar }
\end{aligned}
$$

\section{TURBOCHARGER DEVELOPMENT}

\section{INTAKE BOOST REGULATION}

Initial development commenced with no form of turbocharger control, relying on correct turbocharger matching and choked flow through the intake restriction to limit airflow and avoid compressor surge. 
However, experimentation found it advantageous to limit the pressure drop across the choked nozzle in order to minimise the flow losses through the restrictor and thus maximise induced mass flow. This pressure drop across the nozzle was verified using upstream and downstream absolute pressure sensors, thus verifying when the intake system was running in a choked condition over half of the speed range $[1,2,3,4]$. Limiting the pressure drop also minimized the turbocharger compressor pumping work and backpressure, as there was no need to continue pumping against an already choked nozzle. Other advantages included reduced intake manifold air temperatures (MAT), which reduced knock tendency and surge probability. Thus turbocharger control was finally achieved using the internal wastegate, which allowed the exhaust gas to bypass the turbine. A diaphragm operated actuator with reference to MAP controlled wastegate movement, with the reference signal manipulated via a bleed valve. The bleed valve was controlled through the EMS, thus allowing the turbocharger to be electronically controlled at user defined functions of engine speed and throttle position (TP).

\section{TURBOCHARGER COOLING}

The OEM supplied GT-12 unit featured water cooling in the centre bearing housing to improve turbocharger reliability. Water cooling prevented problems associated with turbocharger heat soak after heavy running and rapid shut down. This had been a major issue in previous turbocharger programs at the University of Melbourne $[10,11]$. The problem affects shaft and bearing reliability as the high temperatures can force the oil within the turbocharger to carbonise, resulting in subsequent bearing failure on restarting.

Turbocharger development commenced with water cooling. However, this led to major engine cooling problems as a result of poor implementation, which resulted in several engine failures. The water flow path through the engine had been compromised, as the majority of flow bypassed the engine and flowed through the turbocharger. This problem was eventually discovered but further magnified by the use of an inadequate electric booster pump.

To reduce the mass and complexity of the cooling system, the turbocharger was developed without the water cooling feature. This was achieved by sealing the water cooling jacket within the turbocharger and filling the cavity with a high temperature medium. This promoted inner core heat transfer through the body to the atmosphere, as the insulating air gap had been removed. High temperature synthetic oil was used as the medium, with recorded centre bearing cavity temperatures not exceeding $160^{\circ} \mathrm{C}$, even after hard running and rapid shut down. To further reduce the likelihood of oil carbonizing, a high quality synthetic oil was used. This synthetic oil has a higher flash temperature compared to older mineral based oils. No shaft or bearing problems were recorded after two years and hundreds of hours of engine operation.

\section{TURBOCHARGER OIL CONTROL}

Initial turbocharger development involved installing the as supplied unit in order to quantify oil consumption amounts, with a sectional view displayed in Figure 5. It was originally thought that the induced oil could be trapped and collected in the intake plenum, as the trumpets were raised from the plenum floor. However, oil losses were excessive, with several liters consumed at idle conditions after short running. Several methods of controlling turbocharger oil consumption were attempted and are outlined chronologically in Table 2, along with their affects on oil consumption rates.

The first attempt to solve the oil consumption problem involved limiting the oil supply flow to the turbocharger and increasing the drain size. This provided adequate lubrication and reduced oil losses but was only partially successful. Due to its success, this method was incorporated into all further developments.

Table 2: Methods and resulting affects for controlling turbocharger oil consumption under throttled conditions (idle$2300 \mathrm{rev} / \mathrm{min}, 50 \mathrm{kPa}$ MAP, $250 \mathrm{kPa}$ turbocharger oil pressure).

\begin{tabular}{|c|c|c|c|}
\hline & $\begin{array}{l}\text { URBOCHARGER OIL } \\
\text { CONTROL METHOD }\end{array}$ & $\begin{array}{c}\text { OIL RECOVERED } \\
\text { FROM PLENUM, } \\
\text { IDLE CONDITIONS } \\
\text { (L/hr) }\end{array}$ & COMMENTS \\
\hline & As supplied & $5-8$ & $\begin{array}{l}\text { High oil pooling and } \\
\text { exhaust smoke }\end{array}$ \\
\hline & $\begin{array}{l}\text { 1) + limited oil supply } \\
\text { flow and increased } \\
\text { drain size }\end{array}$ & $3-4$ & $\begin{array}{l}\varnothing 1.6 \mathrm{~mm} \text { oil line } \\
\text { restriction fitted, drain } \\
\text { size to match } \\
\text { turbocharger housing }\end{array}$ \\
\hline 3) & $\begin{array}{l}\text { 2) + check valve } \\
\text { accumulator system }\end{array}$ & $3-4$ & Unsuccessful \\
\hline 4) & $\begin{array}{l}\text { 2) + externally } \\
\text { scavenging }\end{array}$ & 0 & $\begin{array}{l}\text { Successful at idle but } \\
\text { not at MAP values } \\
\text { below scavenge } \\
\text { (sudden tip-out) }\end{array}$ \\
\hline 5) & $\begin{array}{l}\text { OEM supplied carbon } \\
\text { face seal }\end{array}$ & 0.1 & $\begin{array}{l}\text { Increased turbo-lag } \\
\text { and shaft loading, } \\
\text { exhaust smoke upon } \\
\text { sudden tip-out }\end{array}$ \\
\hline 6) & $\begin{array}{l}2)+ \text { new compressor } \\
\text { seal housing with } \\
\text { reduced escape area } \\
(1 \text { ring) }\end{array}$ & 1 & $\begin{array}{l}\text { Some improvement, } \\
50 \% \text { reduction in oil } \\
\text { escape area }\end{array}$ \\
\hline 7) & $\begin{array}{l}\text { Modified 6) with } \\
\text { labyrinth annulus (1 } \\
\text { ring) }\end{array}$ & 0.7 & $\begin{array}{l}\text { Continued } \\
\text { improvement }\end{array}$ \\
\hline 8) & $\begin{array}{l}\text { Modified } 7 \text { ) gapless } \\
\text { ring seal ( } 2 \text { rings in } 1 \\
\text { groove) }\end{array}$ & 0.5 & $\begin{array}{l}\text { Exhaust smoke on } \\
\text { sudden tip-out }\end{array}$ \\
\hline 9) & $\begin{array}{l}\text { Modified } 7)+2 \text { rings } \\
\text { in separate grooves }\end{array}$ & 0.2 & $\begin{array}{l}\text { Silver soldered } \\
\text { centre bearing } \\
\text { housing }\end{array}$ \\
\hline 10) & $\begin{array}{l}\text { 9) with vent between } \\
\text { both ring seals }\end{array}$ & 0 & $\begin{array}{c}\varnothing 1.6 \mathrm{~mm} \text { vent. No } \\
\text { exhaust smoke on } \\
\text { tip-out }\end{array}$ \\
\hline
\end{tabular}




\section{OEM GT-12 TURBOCHARGER (as supplied)}

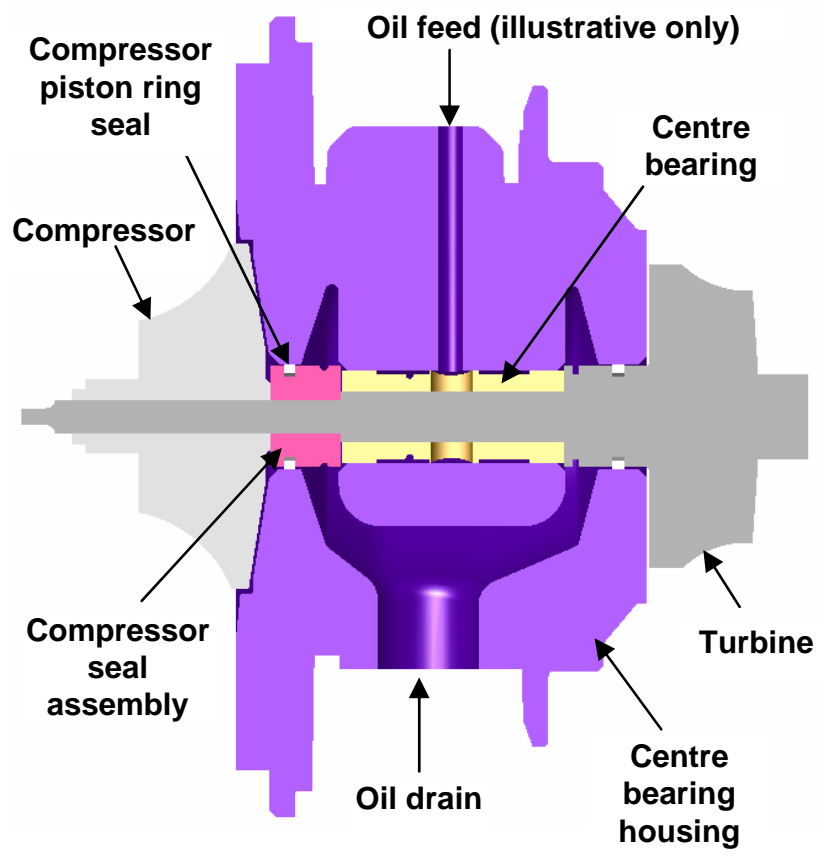

FINAL OIL SOLUTION (Method 10)

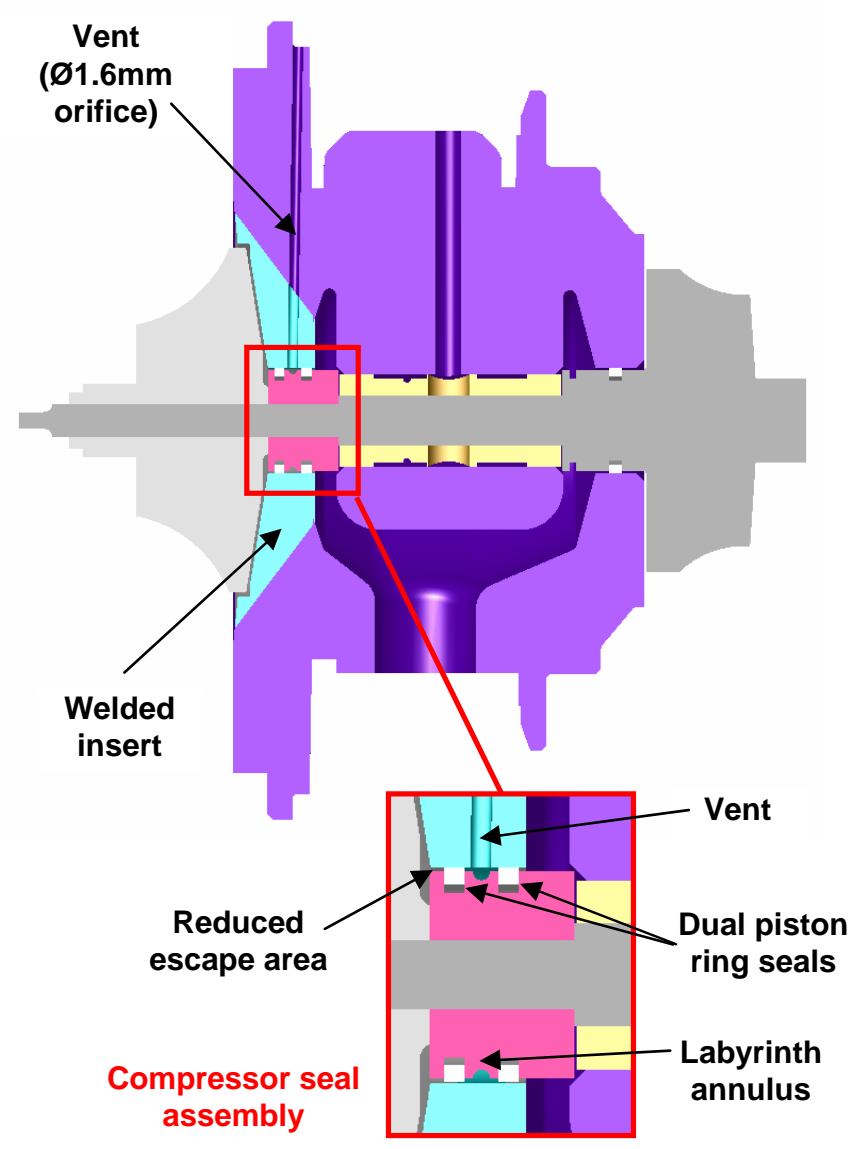

Figure 5: (Upper): Sectional view of the OEM supplied GT-12 turbocharger. (Lower): Sectional view of the redesigned turbocharger to overcome oil consumption problems under throttled conditions. (Note): Water cooling jacket detail removed and oil feed relocated for illustrative purposes only.
The second method involved the use of a check valve accumulator system, which attempted to equalise the pressure across the compressor side seal at engine vacuum conditions. At these conditions, oil would be stored in an accumulator pot, which would then empty under boosted conditions. However, high pressure losses across the check valves and high opening (cracking) pressures resulted in the system failing. Following this, turbocharger oil drain scavenging via an electric external source was attempted. If successful, a dry sump scavenge pump may have been implemented. Scavenging proved successful at MAP values above the scavenge pressure. However, oil losses and exhaust smoke occurred on sudden throttle tip-out, as MAP would drop to $20 \mathrm{kPa}$. Although unsuccessful, this result indicated that further development should be focused on preventing the oil from escaping, rather than trying to draw the oil out from the drain with scavenge.

Development ceased momentarily when an OEM modified unit, retro-fitted with a carbon face seal was supplied by the manufacturer. Although the new unit substantially reduced oil loses, the problem was not completely solved. The implementation of the carbon face seal also reduced turbocharger spool rates. Turbocharger reliability issues due to the higher shaft loading from the seal drag were also of concern, with several competing Formula teams experiencing shaft failures in competition. Thus the carbon face seal was dismissed in future developments.

Subsequently, the internals of the turbocharger were modified with development focusing on the compressor seal assembly. A new compressor seal housing with an increased outside diameter was implemented. This design increased the pressure drop across the seal and limited the oil escape path. The enlarged housing further reduced oil losses and was incorporated into later designs. However, as a result of the enlarged housing, the rotating assembly was more prone to surface rubbing as the bearing or shaft deteriorated. This was combated by compressor seal housing material selection and the fact that the two surfaces could act as a plain bearing. Incorporating a labyrinth annulus seal in the housing further increased the pressure drop and was implemented in future developments. Although significant oil consumption improvements were made with this housing and seal package, additional development was still required to eliminate the problem.

The next stage involved incorporating a gapless ring seal to eliminate the ring end gap. This was achieved by placing two ring seals in a widened groove. This was only partially successful and concluded that only a minor portion of oil consumption was attributed to the ring seal end gap. This suggested further improvement could be achieved by separating the two seals to maximise the pressure drop across the sealing system. However, developments were still limited by piston ring seal location, due to the minimal centre bearing housing land area. The land area was increased by machining the centre bearing housing to accommodate an insert, which was silver soldered to the housing and later machined to 
dimensional tolerance. This allowed two ring seals to be implemented, separated by the labyrinth annulus seal as seen in Figure 5 and 6 . The piston ring seals were rotated by $180^{\circ}$ with respect to each other, in order to minimise the ring end gap affects. This further reduced oil loss and the final solution built on this concept. This solution involved venting the labyrinth annulus cavity to atmosphere. This was achieved by drilling a single 1.6 $\mathrm{mm}$ diameter orifice through the centre bearing housing, as depicted in Figure 6. This solved the oil issue as what little vacuum escaped past the first seal, would induce air rather than suck oil past the second seal.

The final seal design featured excellent oil retention with no oil film in the intake system, even after several months of dynamometer and vehicle operation. This oil retention is further illustrated by the hydrocarbon $(\mathrm{HC})$ emissions, with recorded values of $30 \mathrm{ppm}$ at throttled conditions.

\section{CENTRE BEARING HOUSING}

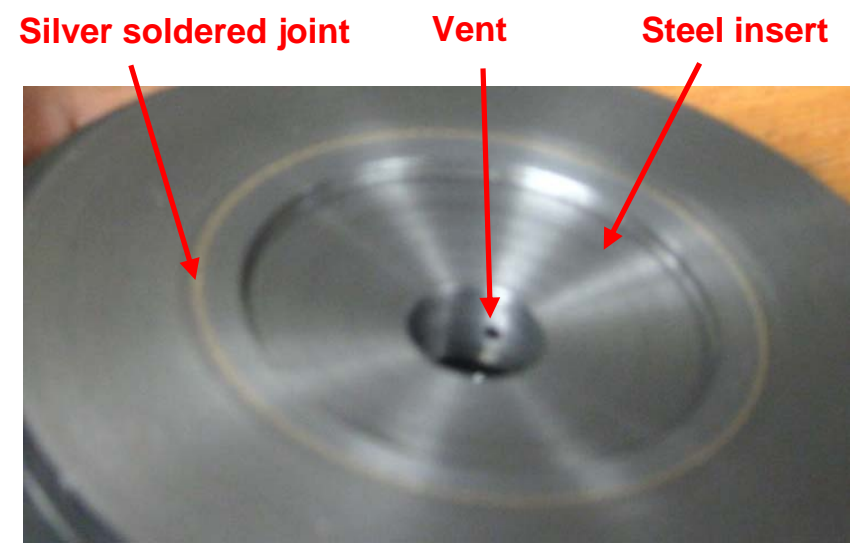

\section{ROTATING ASSEMBLY}

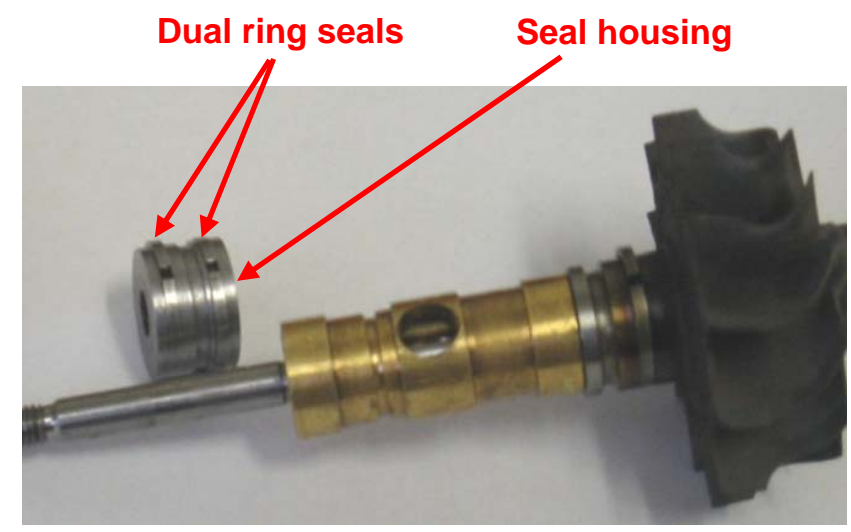

Figure 6: Method 10 - Components used to overcome the oil control issue (Upper): Modified centre bearing housing with silver soldered insert and vent orifice. (Lower): Rotating assembly with new compressor seal assembly.

\section{EXHAUST MANIFOLD GEOMETRY}

Exhaust manifold design was heavily influenced by the unequal pulse effects, attributed to the uneven firing order of this engine. The unequal pulsing caused problems ranging from exhaust turbine velocity fluctuations to ineffective cylinder scavenging, which limited achievable boost pressures. The ineffective cylinder scavenging resulted in high residual gas fractions, which decreased performance and increased knock tendency.

To investigate this effect, several exhaust manifold concepts were proposed. The first implemented pulse type turbocharging, with unequal exhaust primary lengths to compensate for the odd pulsing. Pulse type turbocharging is beneficial, as it has advantages associated with reducing turbocharger spool time and delivering higher pressure ratios $[8,9]$. However, this design had limitations in that the exhaust lengths were speed dependent and thus the system could only be tuned to eliminate odd pulsing at a given speed. Constant pressure turbocharging, featuring an exhaust plenum chamber, was also investigated as it smoothed the flow into the exhaust turbine. However, the increased manifold surface area increases the heat losses and reduces turbocharger delivered enthalpy. The exhaust manifold geometry for both systems together with other parameters was investigated with the help of an experimentally validated 1D CFD simulation model $[1,3]$. This model was produced using Ricardo's WAVE $®$, with the block diagram and simulation results for varying exhaust geometry shown in Figure 7.
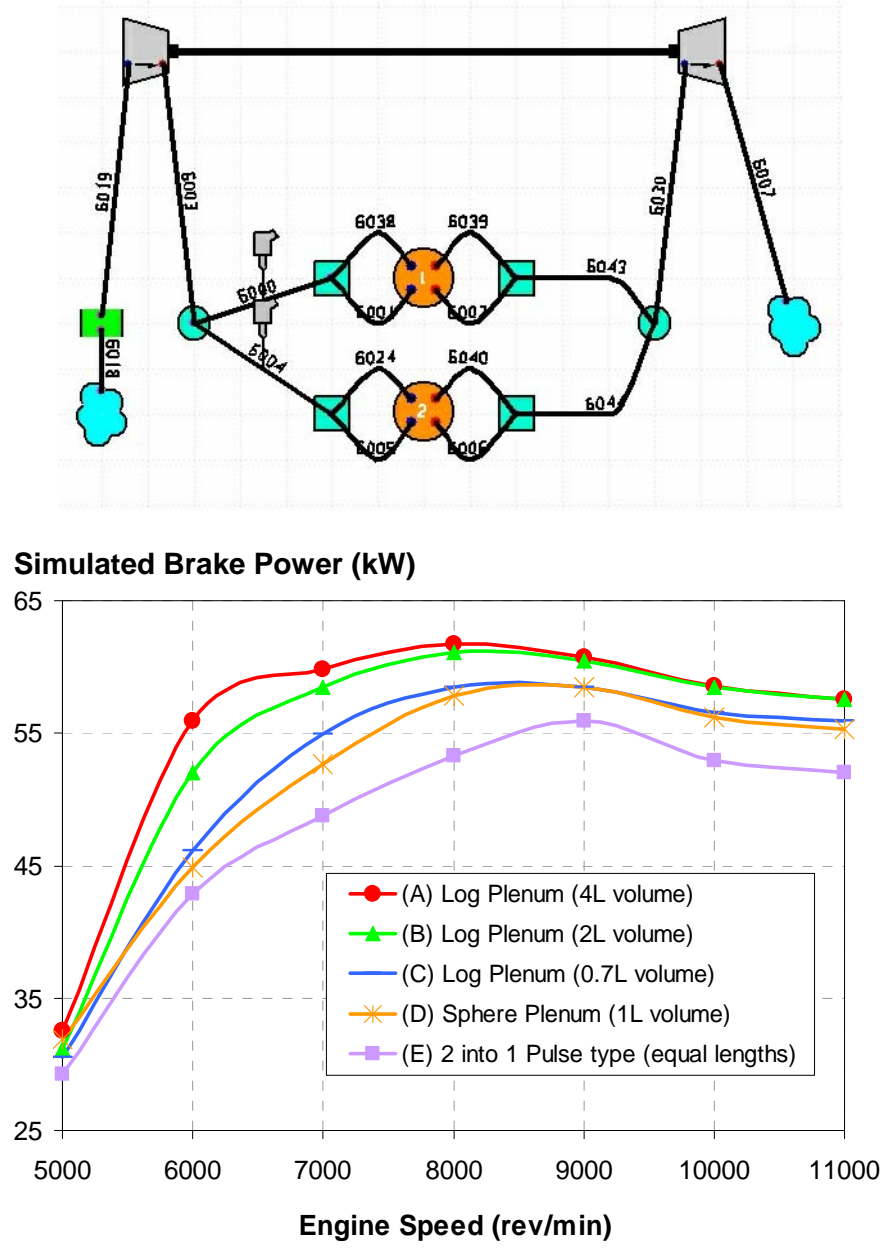

Figure 7: (Upper): WAVE $®$ model used for optimisation. (Lower): Simulated results with constant pressure and pulse type turbocharging. 
Simulation results from Figure 7 show significant brake power improvements when employing constant pressure type turbocharging to this particular odd firing engine. The reduced performance of the equal length pulse type setup is evident across all speeds, as the increased residual gas content reduces air consumption. It is also noted that as a consequence of the engine design, all experimental and simulated data presented corresponds to the performance at the gearbox output shaft and not at the crankshaft. Performance at the crankshaft is expected to be marginally higher, due to the reduction in losses associated with driving the transmission components.

Performance increases are associated with increasing the exhaust manifold volume, as this reduces the pulsing effect thus reducing the exhaust turbine velocity fluctuations and increasing delivered boost. This effect is most dominant at lower engine speeds, prior to the intake restriction limiting airflow. The odd pulsing effects decrease with increasing engine speed, due to the reduced time intervals. From the simulation results, an exhaust manifold geometry with a volume of four liters was selected. Larger volumes provided small gains in output but are coupled with increased heat losses and transport times and thus were not used.

The most efficient plenum geometry was thought to be a sphere, as this has the minimum surface area to volume ratio, reducing heat losses. However, simulation results showed that the log style plenum had reduced flow losses for similar volumes and so was employed. The log style plenum also permitted the adoption of Watson's KEC rolling flow design, which had been used successfully in intake manifolds [1,2,5], but as yet had not been implemented to exhaust manifold designs.

Figure 8 displays both exhaust manifold designs used during testing, with more detail given in the exploded views of Appendix A. Development commenced with the exhaust plenum design, however, as a result of thermal cracking, the plenum was replaced during development in favor of the simple two into one pulse manifold. With this manifold design, engine torque was reduced by as much as 30\% as shown in Figure 9, with severe knock problems at previously determined MBTspark timing values.
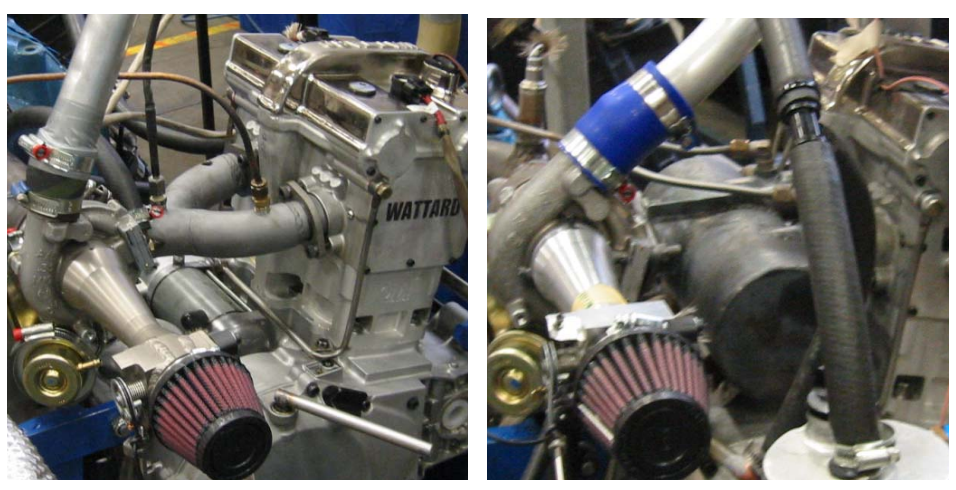

Figure 8: Varying exhaust manifold geometry, (Left) two into one pulse system (model E), (Right) Watson's KEC plenum system (model A) optimized through WAVE®.

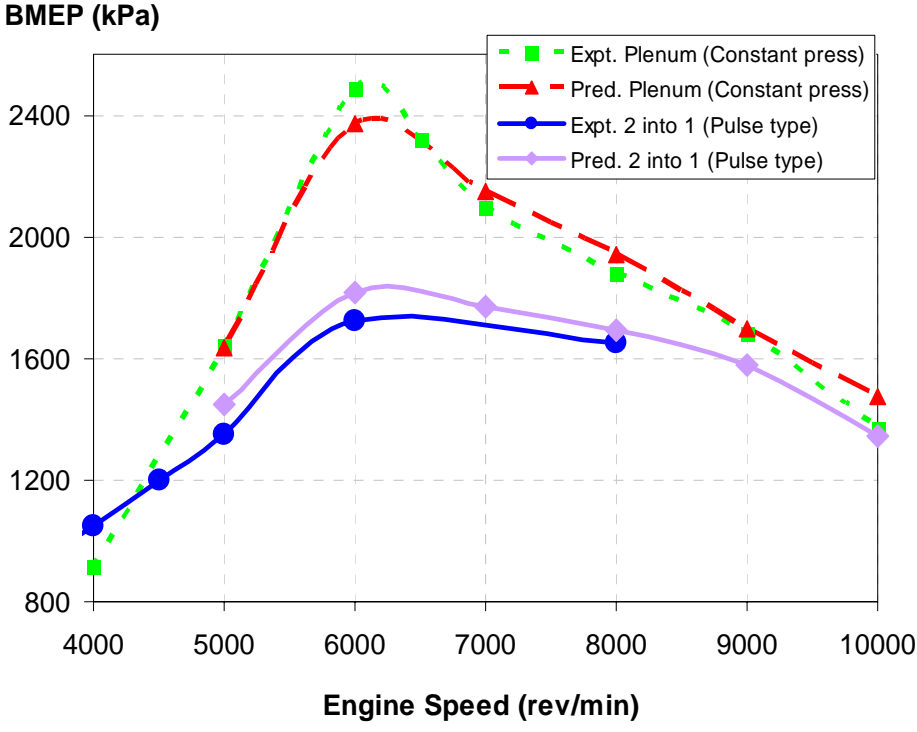

Figure 9: BMEP experimental and simulation results for constant pressure and pulse type turbocharging, highlighting the performance differences due to exhaust manifolding for an odd firing engine.

In order to avoid the $\mathrm{DL}$ for the given $\mathrm{CR}$ for the two into one pulse manifold, boost levels and spark timing were reduced and thus performance suffered, with experimental results for a fixed speed shown in Figure 10. To improve engine performance and reliability, the initial plenum design was further developed to prevent thermal cracking and was later implemented. This was achieved by changing the material specification from 316 stainless steel to a low carbon mild steel and by increasing the manifold wall thickness.

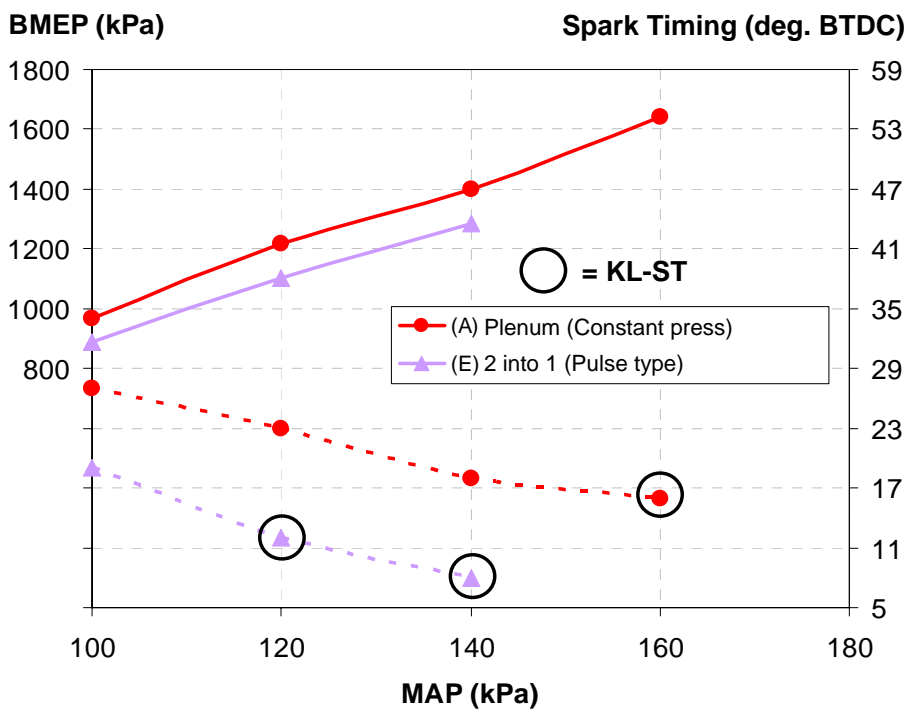

Figure 10: BMEP and spark timing versus MAP for constant pressure and pulse type turbocharging. Experimental results highlight the reduced performance of the two into one pulse type system. (5000 rev/min, 10:1 CR) 


\section{OPERATING LIMITS}

The oil jet cooled, custom forged pistons received considerable development. In order to achieve the final design objectives while operating on 98-RON pump gasoline, the final design featured a reduced compression ratio of 10:1 and an increase in the number of rings from two to three. This reduced blow-by and improved heat rejection to reduce knock intensities to acceptable limits.

Engine development initially commenced with no form of knock detection. This was due to difficulty in physically locating a cylinder pressure transducer in the pent roof combustion chamber. As an alternative, the engine operator was relied upon to audibly discern the knock severity. This proved to be troublesome, with several inlet side top land piston failures occurring early in development (Figure 11). With the engine featuring a gasketless interface, knock above the DL would quickly result in piston failure due to the absence of gasket weakspot [12].

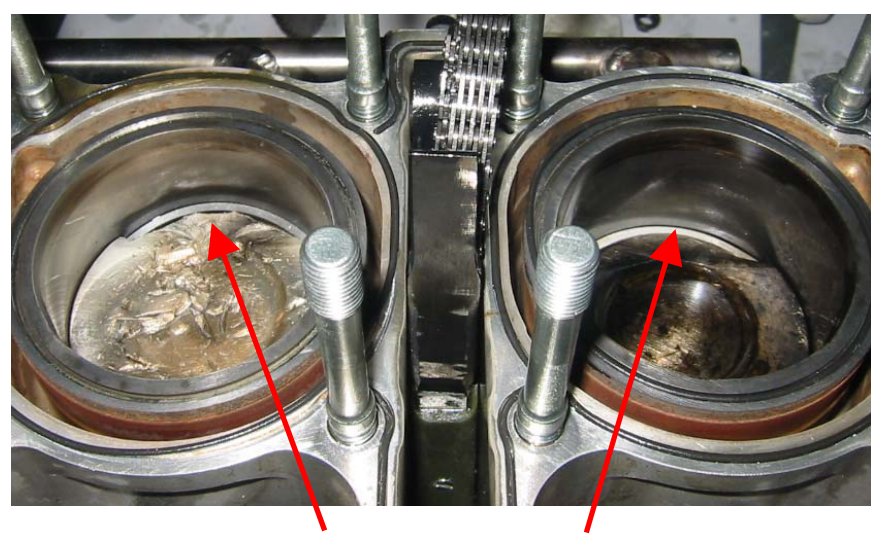

INLET SIDE PISTON LAND FAILURE

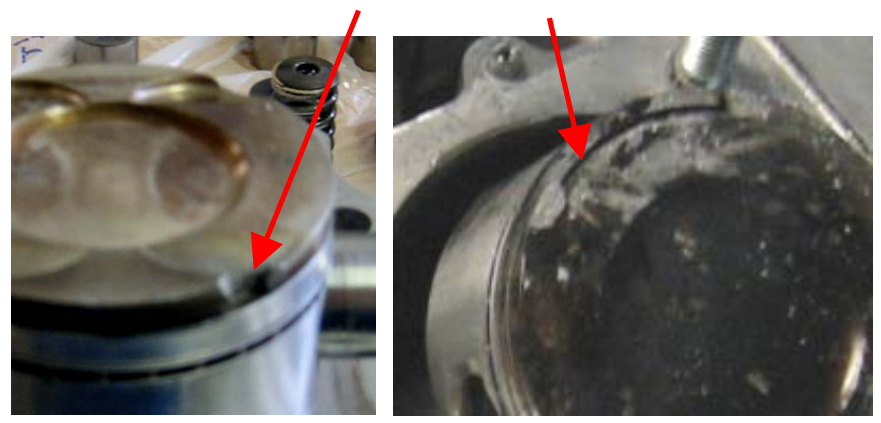

Figure 11: Adverse effects of heavy knock in the end-gas region above the DL. (Upper): Simultaneous inlet side piston land failure in both cylinders. (Lower): Further inlet side failures after increased piston oil cooling, directed towards the piston intake underside.

After several piston failures, A Kistler 601-B1 cylinder pressure transducer was installed and later flush mounted to avoid high resonance signals. This significantly reduced development time, as any form of knock (Figure 12) could be detected and avoided before piston land failure. It is also interesting to note that the audible noise associated with the heavy knocking condition was closer to a high frequency crackle at the elevated engine speeds, quite different to knock in low speed conventional engines.
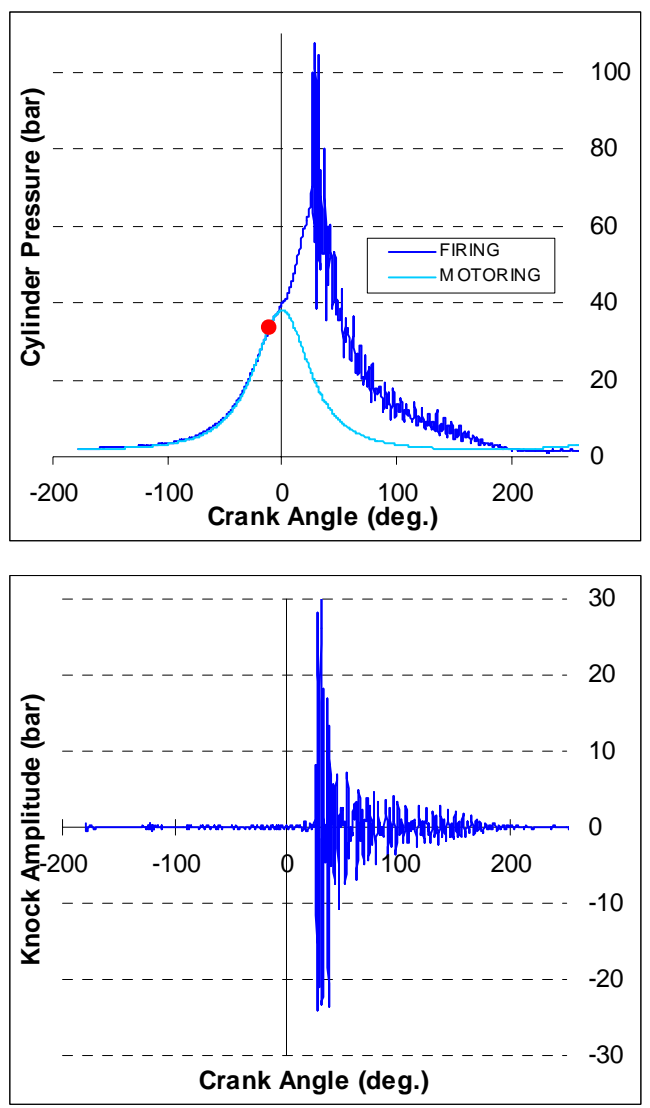

Figure 12: A recorded heavy knocking cylinder pressure cycle, highly TC, $7000 \mathrm{rev} / \mathrm{min}, 11: 1 \mathrm{CR}, 220 \mathrm{kPa}$ MAP

Figure 13 displays the knock and airflow limitations as functions of engine speed, MAP and CR, found from experimental testing. These cross plots have been constructed from multi-CR experimental data points, gathered by incrementally varying the $C R$ to values dictated by the knock severity. These $\mathrm{CR}$ values included 9.6, 10, 11, and 13. Resulting piston crown and combustion chamber shapes associated for each $\mathrm{CR}$ are displayed in Appendix B.

The cross hatched areas in Figure 13, indicate domains where engine operation was $\mathrm{KL}$ but could be controlled via EMS tuning strategies to avoid the DL. The shaded areas in plots indicate where engine operation was not possible due to airflow limitations or heavy knock exceeding the DL. The WOT case for a given CR corresponds to the performance limit $(\mathrm{PL})$ line, with MAP values varying to accommodate the airflow requirements. Thus knock severity is highest at 6000 $\mathrm{rev} / \mathrm{min}$ due to the employed MAP reaching $270 \mathrm{kPa}$. 

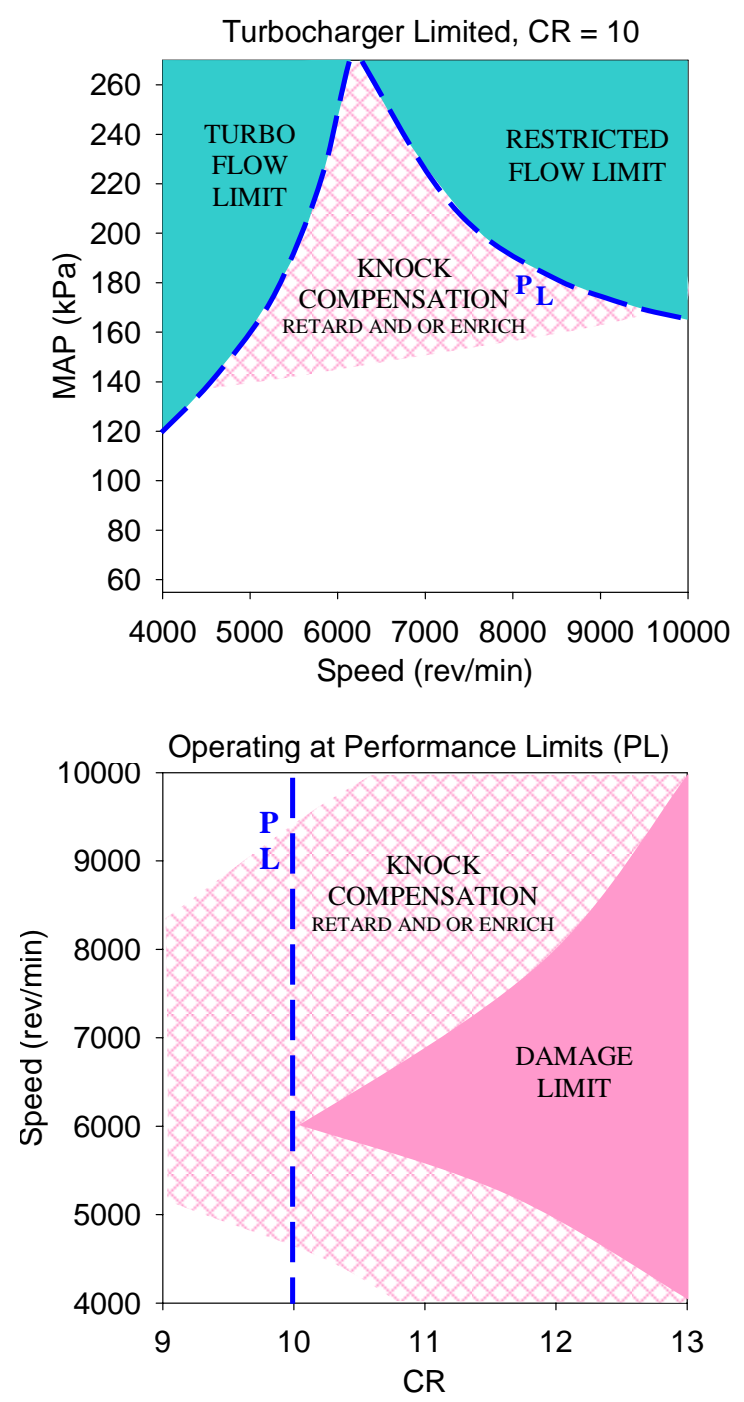

Figure 13: Knock and airflow limitations versus MAP, engine speed and CR. Cross hatched areas indicate operation with spark retard and/or fuel enrichment to compensate for knock. Shaded areas indicate non operation due to knock levels above the DL or limited airflow. PL is the performance limit line defined at WOT.

The data in Figure 13 must be put into context before any conclusions can be drawn. It is noted that increased $\mathrm{CR}$ and or MAP is expected with the implementation of various knock preventive strategies. These strategies could include direct injection (DI), exhaust gas recirculation (EGR), intake charge cooling (intercooling and/or evaporative), combustion enhancement through chamber design and increases in fuel octane number $[14,15,16,17,18,19]$. However, trends confirm that for a given CR and MAP condition, knock is less prone at higher engine speeds $[13,20]$. This is a consequence of the increased flame speeds within the combustion chamber, which consume the unburnt mass in the endgas region more quickly. This decreases the likelihood of knock due to the reduced end-gas residence time within the combustion chamber. Testing also found that spark retard and/or fuel enrichment can be used as a method of knock control for up to 1-2 CR points, depending on the knock severity. This can be a useful tool during boosted engine development, as it allows the calibrator some margin to avoid the DL without having to reduce the $C R$.

\section{RESULTS}

Dynamometer and competition results have highlighted the success of the turbocharger development program. The TC engine package resulted in the Formula vehicle being very competitive in competition, achieving exceptional fuel economy while maintaining excellent power and drivability. The engine was installed into successive MUR Motorsport vehicles in 2003 and 2004 and became the first prototype engine to successfully compete in the competition's 25 year history. In 2004, the engine and car were very competitive, finishing first in the fuel economy event.

Dynamometer results also emphasize the significance of the turbocharger development for the highly TC engine package. Peak BMEP values of 25 bar were observed and are believed to be the highest specific output recorded for small engines operating on pump gasoline $[1,4]$. This surpasses the 22 bar, achieved by GM's TC Ecotec engine [14]. Final brake performance is displayed in Figure 14 and is compared to simulation results and the team's previous powerplant. Performance results show improved brake power output when compared to the Suzuki GSX-R600 due to the reduced frictional losses associated with the downsized capacity. Also evident is the near constant power achieved over half the speed range as the power is limited by sonic flow through the restriction. Excellent agreement between simulation results from WAVE $\AA$ is also evident, with GSX-R600 experimental results used for initial model validation $[1,3]$.

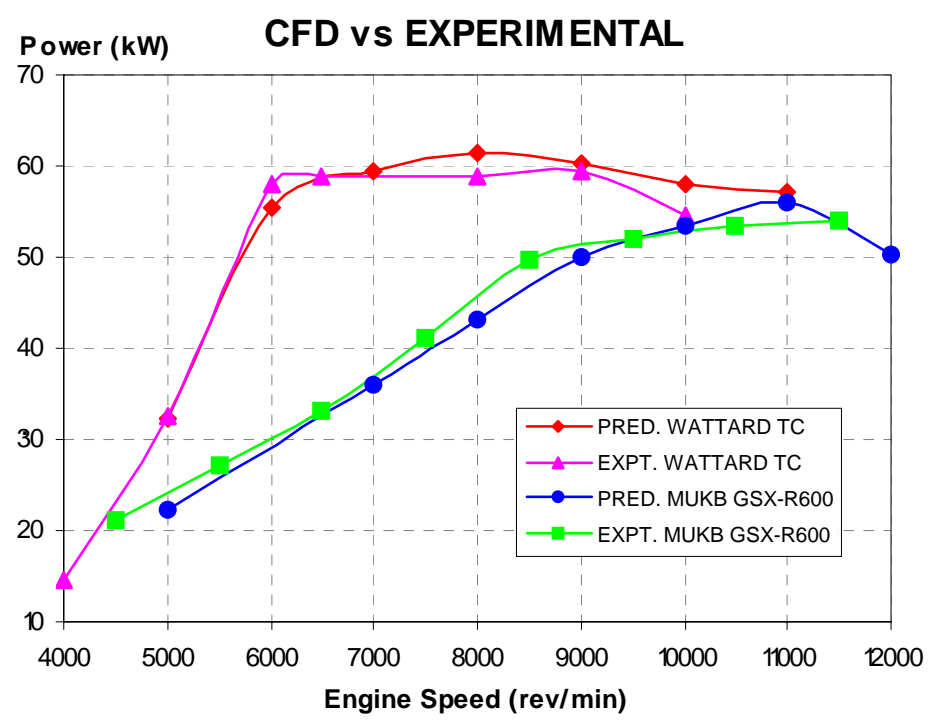

Figure 14: Comparison of experimental and predicted engine performance for both the 'WATTARD' and GSX-R600 engines. 


\section{CONCLUSIONS}

Turbocharger development for a restricted $430 \mathrm{~cm}^{3}$ odd firing two cylinder engine has been described. The downsized test engine used for development was specifically designed and configured for Formula SAE, SAE's student Formula race-car competition.

As a result of the design objectives, high pressure ratio turbocharging was implemented, with MAP values reaching $270 \mathrm{kPa}$ at mid range speeds. However, as a result of the Formula regulated upstream intake restrictor and throttle location, oil consumption issues arose due to compressor throttling.

This problem was compounded as modern turbocharger designs feature piston ring type oil seals on the compressor side. The research and development steps to overcome this oil control issue are outlined, together with a final solution. This development has significant relevance, as it allows the continual use of compressor side piston ring seals, while also allowing the turbocharger to be placed downstream of the throttle. This layout has additional benefits in reducing turbo-lag and increasing spool rates during engine transience.

The TC development methodology has been outlined, together with the importance of simulation as an aid in accelerating engine development. These tools have enabled improved performance and understanding at reduced costs and lead times.

Exhaust manifold effects on turbocharger implementation are investigated for both pulse and constant pressure type systems. Results from simulation and experimentation show significant brake power improvements when employing constant pressure type turbocharging to this particular odd firing engine.

Operating limits are also outlined in order to achieve 25 bar BMEP, believed to be the highest recorded for small engines operating on pump gasoline. Knock has been highlighted as being the most important limiting factor in defining the performance for small highly TC engines. Testing demonstrated that spark retard and/or fuel enrichment can be used as a method of knock control for up to 1-2 CR points depending on the knock severity.

Dynamometer results show that by successfully implementing turbocharging to Formula applications, near constant power can be achieved over half the speed range. This is due to the regulated intake restriction, which limits airflow and thus performance. The engine was installed in successive MUR Motorsports vehicles and finished first in the fuel economy event at the 2004 competition.

No turbocharger problems were evident after initial development, with the engine completing two years and hundreds of hours of static and transient experimentation.

\section{ACKNOWLEDGMENTS}

The authors are thankful for the patience, support and understanding of family and friends as days would go by where the team would not leave the thermodynamics lab. The authors would also like to thank the Australian division of Garrett Turbochargers for the components supplied together with technical drawings and information. Thanks are also due to Elisa Toulson for her efforts in reviewing the technical writing of this paper. The team is also grateful, to all academic, postgraduate, and technical staff involved for their persistence, patience and support during the most trying times. Who said engine development was easy?

To the generous sponsors that made the UniMelb 'WATTARD' engine possible, we offer our sincere thanks for supporting the excellent learning activity at the University of Melbourne.

$>$ APEP Pistons -

$>$ Argo Engineering -

$>$ Bishop Innovation -

> Bohler Uddeholm -

$>$ CadCore Pty Ltd -

$>$ Concentric Asia Pacific -

$>$ Cosway Motorcycles -

$>$ Davies Craig -

$>$ Electromold -

$>$ Farley Laserlab -

$>$ Garrett Honeywell -

$>$ Kawasaki Australia -

$>$ Magnesium Technologies -

$>$ MAME Centre for Manufacturing -

$>M \& W$ Ignitions -

$>$ Penrite Lubricants -

$>$ QMI Solutions -

$>$ Ricardo -

$>$ Robert Bosch -

$>$ Siemans VDO -

$>$ Southside Cylinder Heads -

$>$ University of Melbourne -

$>$ Wade Camshafts -

$>$ Whitehorse Industries -

Tas, Australia

Vic, Australia

NSW, Australia

NSW, Australia

Vic, Australia

Vic, Australia

SA, Australia

Vic, Australia

Vic, Australia

Vic, Australia

Vic, Australia

NSW, Australia

NSW, Australia

Vic, Australia

Vic, Australia

NSW, Australia

Vic, Australia

QId, Australia

Sussex, UK

Vic, Australia

Vic, Australia

Vic, Australia

Vic, Australia

Vic, Australia

Vic, Australia

\section{NOMENCLATURE}

BMEP brake mean effective pressure

CA crank angle

CR compression ratio

DI direct injection

DOHC double overhead camshafts

DL damage limit

EGR exhaust gas recirculation

EMS engine management system

EVC exhaust valve closed

EVO exhaust valve open

GM General Motors

HC hydrocarbon 


$\begin{array}{ll}\text { IVC } & \text { inlet valve closed } \\ \text { IVO } & \text { inlet vale open } \\ \text { KA } & \text { knock amplitude } \\ \text { KEC } & \text { kinetic energy conservation } \\ \text { KL } & \text { knock limit } \\ \text { MAP } & \text { manifold absolute pressure } \\ \text { MAT } & \text { manifold air temperature } \\ \text { MBT } & \text { maximum brake torque } \\ \text { MUR } & \text { Melbourne University Racing } \\ \text { PFI } & \text { port fuel injection } \\ \text { NA } & \text { normally aspirated } \\ \text { PL } & \text { performance limit } \\ \text { RON } & \text { research octane number } \\ \text { SC } & \text { supercharged } \\ \text { SI } & \text { spark ignition } \\ \text { ST } & \text { spark timing } \\ \text { TC } & \text { turbocharged } \\ \text { TP } & \text { throttle position } \\ \text { WOT } & \text { wide open throttle }\end{array}$

\section{REFERENCES}

1. ATTARD, W, 'Design, Performance and Analysis of a Downsized Highly Turbocharged $0.45 \mathrm{~L}$ Formula SAE Engine', Current Ph.D. Thesis, Mech. Eng. Dept., Univ. of Melbourne. (2006)

2. ATTARD, W. and WATSON, H.C., 'Development of a 430cc Constant Power Engine for FSAE Competition', SAE paper 2006-01-0745. (2006)

3. ATTARD, W., WATSON, H.C. and KONIDARIS, S., 'Highly Turbocharging a Restricted, Odd Fire, Two Cylinder Small Engine - Design, Lubrication, Tuning and Control', SAE paper 2006-01-3637. (2006)

4. ATTARD, W., WATSON, H.C., KONIDARIS, S. and KHAN, M., 'Comparing the Performance and Limitations of a Downsized Formula SAE engine in Normally Aspirated, Supercharged and Turbocharged Modes', SAE paper 2006-32-0072. (2006)

5. KARAGOUNIS, T. and STRAUS, 'Development of a 90 bhp Turbocharged Engine for use in Formula SAE-A', Undergraduate Thesis, Mech.Eng. Dept, Univ. of Melbourne. (2002)

6. MILIKEN, W.F. and MILIKEN, D.L., 'Race Car Vehicle Dynamics', ISBN 1-56091-526-9. (2005)

7. WATSON, H.C. and MILKINS, E.E., 'Power Generation Systems', Lecture Notes, University of Melbourne. (2003)

8. WATSON, N. and JANOTA, M.S., 'Turbocharging the Internal Combustion Engine', Macmillan Press, ISBN 0-333-242904. (1982)

9. MacINNES, H., 'Turbochargers', HP Books, ISBN 0912656-49-2. (1984)

10. ROSENKRANZ, H.G., WATSON, H.C., BRYCE, W. and LEWIS, A. 'Driveability fuel consumption and emissions of 1.3 litre turbocharged spark ignition engine developed as a replacement for a 2 litre normally aspirated engine.' Proc. I.Mech.E., C118/86:139-150 pp. (1986)

11. WATSON, H.C., MILKINS, E.E., ROBERTS, K. and BRYCE, W., 'Turbocharging for Fuel Efficiency, SAE paper 830014. (1983)

12. ATTARD, W., WATSON, H.C. and STRYKER, P., 'Design and Development of a Gasketless Cylinder Head/Block Interface for an Open Deck, Multi Cylinder, Highly Turbocharged Small Engine', SAE paper 2006-32-0036. (2006)

13. ROTHE, M., HEIDENREICH, T., SPICHER, U. and SCHUBERT, A., 'Knock Behaviour of SI Engines: Thermodynamic Analysis of Knock Onset Locations and Knock Intensities', SAE paper 2006-01-0225. (2006)

14. Automotive Engineering International, 'Traveling the Long Road to Gasoline Direct Injection', SAE International, June. (2006)

15. LAKE, T., STOKES, J., MURPHY, R., OSBORNE, R. and SCHAMEL, A., 'Turbocharging Concepts for Downsized DI Gasoline Engines', SAE paper 200401-0036. (2004)

16. CAIRNS, A., BLAXILL, H., IRLAM, A., Exhaust Gas Recirculation for Improved Part and Full Load Fuel Economy in a Turbocharged Gasoline Engine', SAE paper 2006-01-0047. (2006)

17. HEYWOOD, J., 'Internal Combustion Engine Fundamentals', ISBN 007028637X. (1988)

18. GERTY, M., and HEYWOOD, J. B., 'An Investigation of Gasoline Engine Knock Limited Performance and the Effects of Hydrogen Enhancement', SAE paper 2006-01-0228. (2006)

19. TAYLOR, C.F., 'The Internal Combustion Engine in Theory and Practice', Vol. 1 and 2, ISBN 0262700271. (1977)

20. OTOBE, Y., GOTO, O., MIYANO, H., KAWAMOTO, M., AOKI, A. and OGAWA, T., 'Honda Formula 1 Turbocharged V6 1.5 liter Engine', SAE paper 890877. (1989)

\section{CONTACT}

Prof. Harry Watson

Head Thermofluids Group

Department of Mechanical Engineering

University of Melbourne

Victoria, Australia, 3010

Email: harrycw@unimelb.edu.au

William Attard

Thermofluids Group

Department of Mechanical Engineering

University of Melbourne,

Victoria, Australia, 3010

Email:william_attard@hotmail.com 

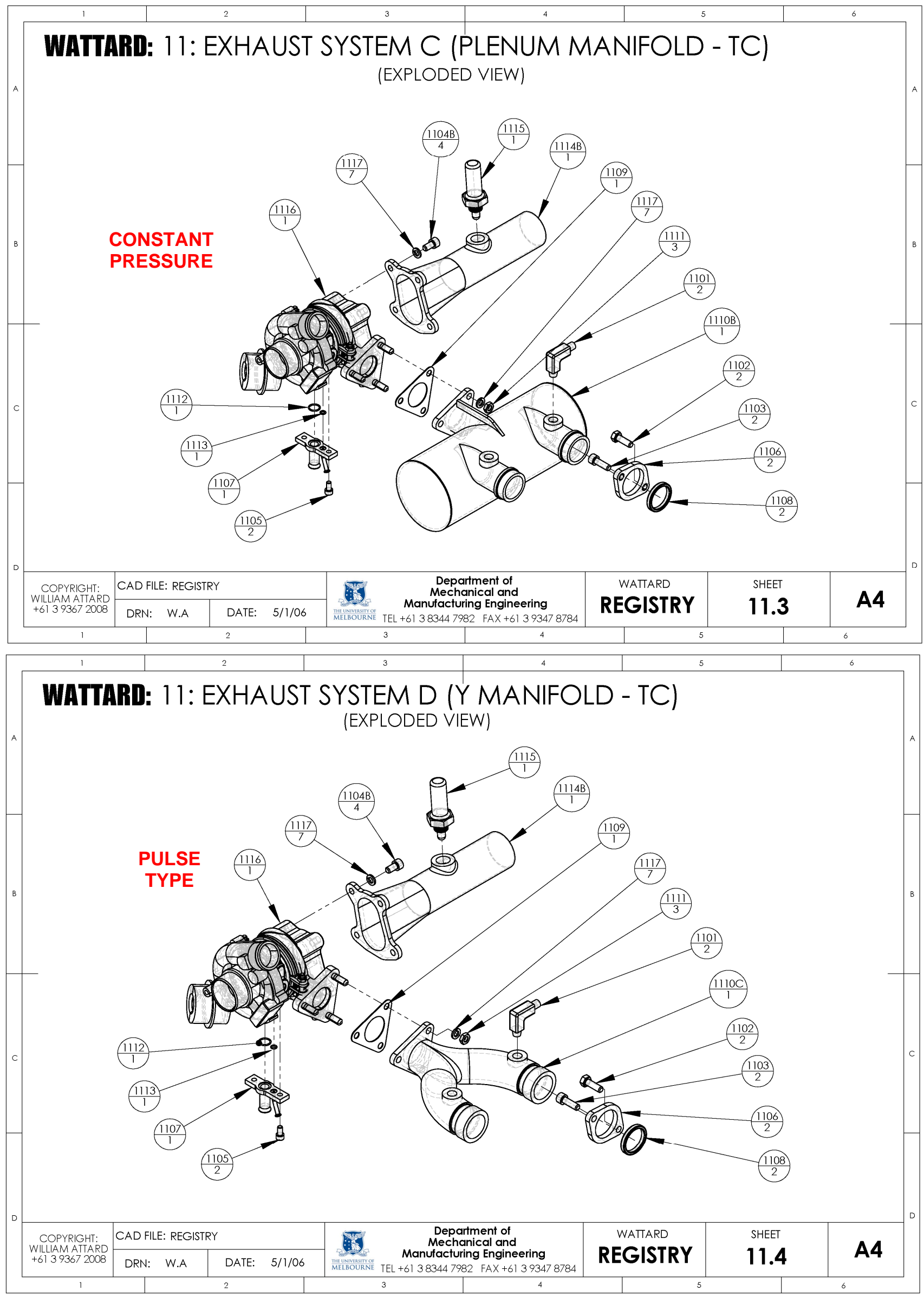


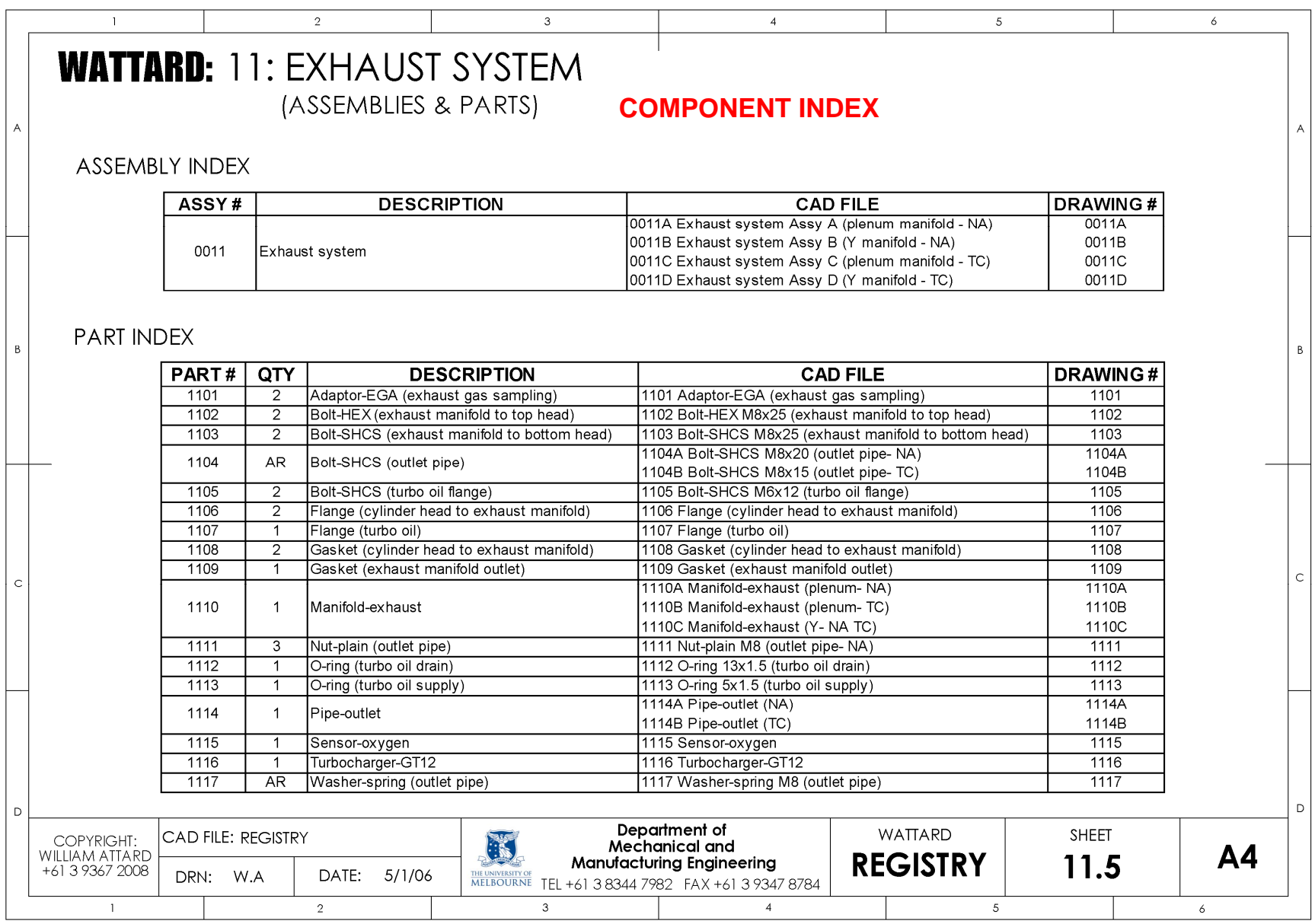

\section{APPENDIX B: VARYING PISTON DESIGNS}

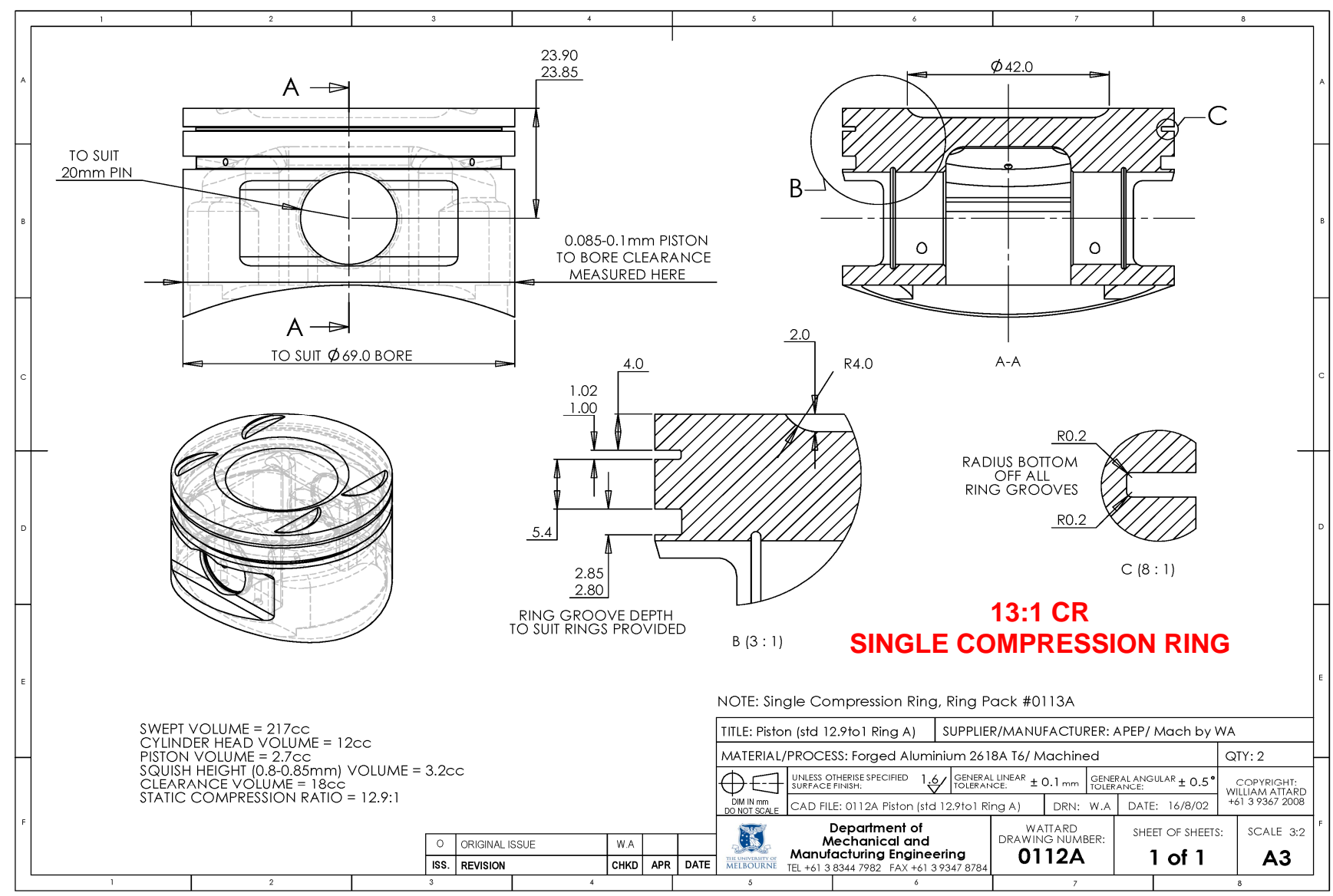



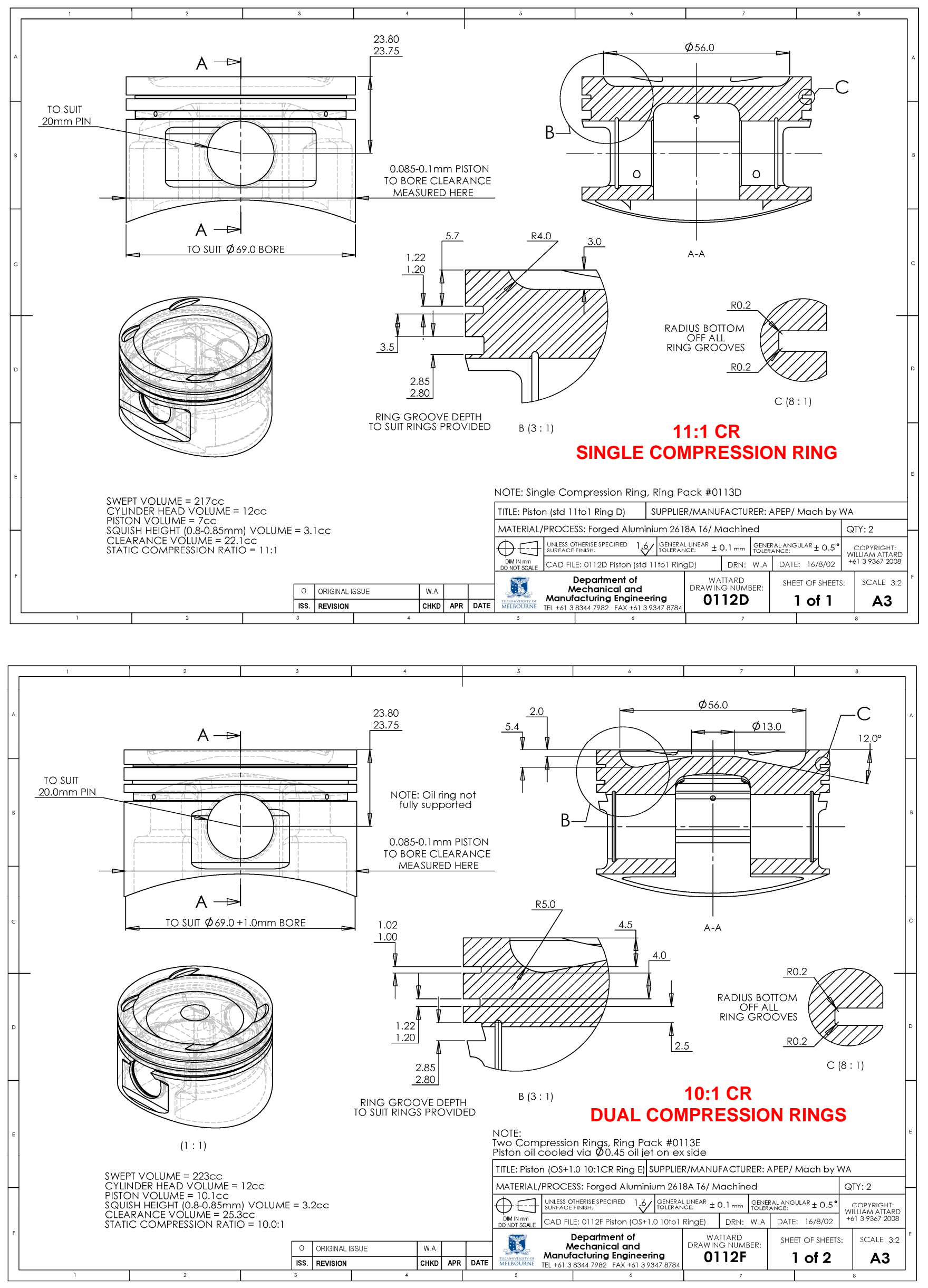


\section{University Library}

\section{- M M I N E R VA A gateway to Melbourne's research publications}

Minerva Access is the Institutional Repository of The University of Melbourne

Author/s:

Attard, William;Watson, Harry;Konidaris, Steven

Title:

Highly turbocharging a restricted two cylinder small engine: turbocharger development

Date:

2007

Citation:

Attard, W., Watson, H., \& Konidaris, S. (2007). Highly turbocharging a restricted two cylinder small engine: turbocharger development. In, Proceedings, SAE International World Congress, Detroit, Michigan, USA.

Publication Status:

Published

Persistent Link:

http://hdl.handle.net/11343/34523 